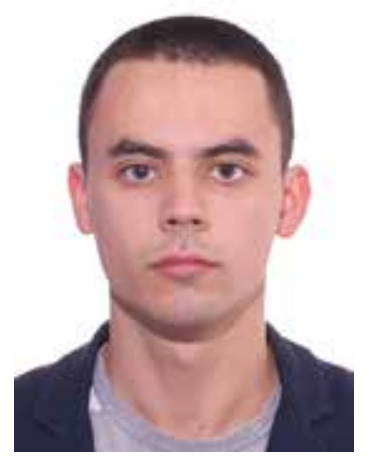

УДК 340.131+342.41

\author{
Олег Голєв, \\ студент I курсу Аругого (магістерського) рівня \\ вишої освіти юридичного фракультету \\ Аьвівського національного університету \\ імені Івана Франка, \\ юрист юридичної компанії «АXELO»
}

https://doi.org/10.32782/2020-38-02

\title{
Пряма дія конституційних прав людини як антикризовий інструмент охорони та захисту прав людини в умовах пандемії COVID-191
}

Кризові процеси в Україні та світі, що пов'язані із триваючим поширенням COVID-19, формують нові виклики для світового співтовариства, чи не найскладнішим з яких є пошук балансу між необхідністю введення карантинних заходів, метою яких $€$ забезпечення безпеки усіх і кожного, та окремими правами людини. У цьому контексті інтереси економіки та охорони здоров'я перебувають у доволі інтенсивній конфронтації. У той час як прихильники «економічно-орієнтованої» моделі регулювання вказують на негативні наслідки для національної економіки в разі запровадження заходів так званого жорсткого карантину, лікарі наголошують на можливості стрімкого поширення COVID-19 у випадку їх невведення.

Метою цієї статті $є$ розкриття значення і ролі прямої дії конституції в якості інструментарію подолання кризових явищ у світлі доктрини прав людини. Результати такого дослідження зможуть підказати нові способи організації державного та суспільного життя в умовах кризових ситуацій, викликаних не лише пандемією, але й іншими загрозами, що можуть виникнути в майбутньому. Відтак існує необхідність розробки антикризового інструменту, що допоможе захистити конституційні права та конституційний лад. Одним із елементів такого інструментарію пропонуємо

${ }^{1}$ Наукові напрацювання із застосування так званої інтегральної методології до розуміння прямої дії конституційних прав попередньо опубліковані в Юридичному науковому електронному журналі (електронне наукове фахове видання юридичного факультету Запорізького національного університету) № 5, 2019 (доступ за посиланням: http://www.lsej.org.ua/5_2019/9.pdf). Основою для написання цієї статті, серед іншого, стали ідеї, здобуті під час навчання в літніх школах з конституційного права, які щороку організовує ОБСЄ для студентів та аспірантів закладів вищої освіти. 
розглядати доктрину прямої дії норм Конституції, яка грунтується на правилах статті 8 Конституції України (далі - Конституція).

Як із цього приводу зазначає Л. Летнянчин, у сучасній науці конституційного права пряма дія Конституції розглядається як складова частина верховенства права, його юридична властивість і конституційний принцип та принцип конституційного ладу [1, с. 117]. На думку М. Савчина, застосування судами положень Конституції як норм прямої дії означає їх чинність як «безпосередньо діючого права» [2, с. 245]. У наведених міркуваннях науковців прослідковується орієнтування на аналіз та оцінку змісту ідеї прямої дії Конституції загалом, без деталізації змісту прямої дії конституційних прав. Хоча, як видається, пряма дія Конституції особливо важлива саме в частині забезпечення прав і свобод людини.

Не заперечуючи цінність попереднього доктринального доробку, тим не менш, варто вказати на те, що в сучасних умовах проблематика прямої дії конституційних прав потребує подальшого дослідження. 3 огляду на це предметом обговорення в цій статті $\epsilon$ пряма дія тих приписів Конституціï, які стосуються визначення змісту гарантованих в ній прав людини, інтерпретованих крізь призму інтегральної методології.

Назва запропонованого підходу може отримати критичну оцінку та викликати подальші дискусії. Проте іiі сутність у цій статті зводиться до відмови від традиційних для вітчизняної науки дефініцій на користь з'ясування змісту механізмів, які сприяють реалізації потенціалу прямої дії конституційних прав людини. Теоретичний базис та рекомендації, пов'язані з іiі практичним застосуванням, містять потенціал, який може бути використаний як антикризовий інструмент в умовах пандемії COVID-19.
Складність осмислення феномену «прямої дії конституційних прав людини» зумовлює необхідність визначення складових частин цього поняття, які дозволять створити додаткові механізми гарантування прав людини. Тому в цій статті пряма дія конституційних прав розглядається як концепція, що знаходить своє вираження у системі принципів, методик та інструментів, що є необхідними для забезпечення безпосереднього застосування конституційних прав. До цієї системи можна зарахувати такі складові частини:

1) виключний предмет правового регулювання Конституції;

2) безпрогальність Конституції;

3) презумпцію верховенства прав людини і автономне тлумачення конституційних категорій [3, с. 41].

Виключний предмет правового регулювання Конституиї (далі виключний предмет) є першою складовою прямої дії конституційних прав людини, яку варто розглядати як певний різновид презумпцій, - йдеться про припущення, що Конституція передбачає вичерпний комплекс конституційно-правових норм, які необхідні для правового регулювання конституційних відносин.

У більшості випадків ми можемо розглядати зазначену презумпцію як спростовну. Проте вона може набувати статусу неспростовної, якщо йдеться про можливість обмеження конституційних прав людини. Ця неспростовність підтверджується, серед усього іншого, нормою статті 22 Конституції, відповідно до якої конституційні права гарантуються і не можуть бути скасовані.

Наведені твердження не можна розглядати як суто теоретичні розмірковування. Так, висловлені ідеї в певній частині вже були застосовані в практиці Конституційного Суду України, зокрема у справі № 1-124/2018 про звернення осіб, визнаних судом недієздатними. У мотивувальній частині Суд 
визнав, що «в деяких випадках Конституція допускає запровадження тимчасових обмежень для громадян у реалізації ними політичного за змістом права брати участь в управлінні державними справами». Проте, як наголосив Суд, «стаття 40 (право звернення до органів публічної влади - О.Г.) Конституції не передбачає можливості обмеження права людини на звернення», що i стало підставою для визнання закону в частині обмеження прав недієздатних осіб на звернення до органів публічної влади неконституційним [4]. Відтак можна доволі однозначно констатувати, що виключний предмет як механізм забезпечення прямої дії конституційних прав людини виявляється в тому, що межі здійснення конкретного права можуть бути передбачені лише в Конституції. Законодавство може лише конкретизувати конституційні норми, проте не створювати нові приписи, які обмежують права людини.

Запропонований механізм забезпечення прямої дії конституційних прав може бути також застосований під час розв'язання проблемних питань, які виникають під час пандемії COVID-19. Оскільки йдеться про ризики неправомірного втручання у права людини під час пандемії коронавірусної інфекції, пропонуємо звернутися до Постанови Кабінету Міністрів України (далі Уряд) «Про запобігання поширенню на території України гострої респіраторної хвороби COVID-19, спричиненої коронавірусом SARS-CoV-2». Так, у відповідності до цієї Постанови (в редакції від 04 квітня 2020 року), було заборонено відвідування парків, скверів, зон відпочинку, лісопаркових та прибережних зон, крім вигулу домашніх тварин однією особою та в разі службової необхідності [5].

Ці урядові обмеження являють собою втручання в конституційне право людини на свободу пересування. Цікаво, що у преамбулі Постанови вказано, що вона «прийнята 3 метою запобігання поширенню на території України гострої респіраторної хвороби COVID-19, спричиненої коронавірусом SARS-CoV-2» [5]. Цей приклад відображає протиріччя, що виникають між потребою гарантування прав людини та суспільними інтересами, пов'язаними із запобіганням COVID-19 на території України.

У цьому контексті виправдано згадати критерії, які використовуються для перевірки конституційності обмежень прав людини. Віднедавна ці критерії значною мірою представлені у практиці Конституційного Суду України. Так, у справі № 1-28/2017 Суд визнав, що «обмеження щодо реалізації конституційних прав і свобод не можуть бути свавільними та несправедливими, вони мають переслідувати легітимну мету, бути обумовленими суспільною необхідністю досягнення цієї мети, пропорційними та обгрунтованими» [6].

Відтак найперше постає питання щодо того, чи уповноважений Кабінет Міністрів України здійснювати подібне втручання у конституційні права людини. У відповідності до статті 33 Конституції, кожен наділений свободою пересування, можливістю вільно обирати місце свого проживання, винятки в реалізації якої встановлюються лише законом. Вузьке розуміння поняття «закону» як виключно Законів України обгрунтовується тим, що лише Законами України визначаються права i свободи людини і громадянина; гарантіі цих прав і свобод; основні обов'язки громадянина [7]. Це дає підстави для висновку, що лише Законами України може бути передбачено обмеження свободи пересування. Водночас на Уряд (у відповідності до статті 116 Конституціï) покладено лише обов'язок вживати заходів щодо забезпечення прав і свобод людини і громадянина.

Отже, аналізована заборона відвідування місць громадського відпочинку (в тому числі парків, скверів 
тощо) нівелює пряму (безпосередню) дію конституційних прав людини. 3 огляду на виключний предмет правового регулювання Конституції, ця урядова заборона суперечить принаймні статтям 8 та 33 Конституції.

Як відомо, наведені вище обмеження конституційних прав стали предметом розгляду Конституційним Судом України у справі № 1-14/2020 (230/20). Ухвалюючи рішення у цій справі, Суд наголосив, що «обмеження конституційних прав може встановлюватися виключно законом - актом, ухваленим Верховною Радою як єдиним органом законодавчої влади в Україні. Встановлення такого обмеження підзаконним актом суперечить статтям 1, 3, 6, 8, 19, 64 Конституції». Водночас Суд уникнув прямої відповіді на питання, чи відповідні положення постанови Уряду відповідають Основному Закону [8]. Позиція Суду була пояснена виявленням підстав для закриття конституційного провадження в цій частині з огляду на втрату чинності акту (його окремих положеннями), щодо якого порушено питання відповідності Конституції.

Наступним елементом прямої дії конституційних прав, який варто розглянути як антикризовий інструмент, є безпрогальність Конституиії. Відсутність прогалин в Конституції дозволяє розглядати iï як самодостатній, незалежний від інших джерел правового регулювання засіб правової охорони основоположних прав і свобод людини. Водночас незалежно від реального контексту Конституція залишається формалізованим текстом, який може потребувати опосередкованої деталізації. А тому, як і будь-який інший нормативно-правовий документ, Конституція може мати недоліки [3, c. 41].

Розглядаючи Конституцію в аксіологічному вимірі, ми дійсно можемо охарактеризувати іiі як безпрогальну. Тому вважаємо, що доктрина безпрогальності органічно доповнює вже розглянутий виключний предмет.
3 огляду на наведене вище виникає питання: якщо Конституція дійсно безпрогальна, то чи містить вона механізм функціонування держави та суспільства в умовах так званої коронавірусної кризи? Вважаємо, що таким механізмом можна визнати інститут надзвичайного стану. Саме його введення могло стати доцільним кроком Президента України та Верховної Ради України замість введення режиму надзвичайної ситуації та карантину. Адже лише в умовах воєнного або надзвичайного стану можуть встановлюватися окремі обмеження прав і свобод із зазначенням строку дії цих обмежень у відповідності до статті 64 Конституції.

Привертає увагу той факт, що статтею 4 Закону України «Про правовий режим надзвичайного стану» встановлена можливість введення надзвичайного стану в разі, inter alia, пандемій, що створюють загрозу життю і здоров’ю значних верств населення [9].

Проте наявний конституційний механізм обмеження прав людини не був використаний. Натомість на початку пандемії COVID-19 (березень 2020 року) Україні був введений правовий режим надзвичайної ситуації, не передбачений Конституцією. Причини невикористання механізмів надзвичайного стану можуть бути різні. Зокрема, не можна виключати, що наявний стан речей є способом пошуку компромісного варіанту між інтересами економіки та потребою в запровадженні заходів для гарантування суспільного інтересу у протидії COVID-19.

Крім того, юридичні особливості правового режиму надзвичайного стану можуть бути непропорційно обтяжливі для конституційних прав людини. Ринкова модель економіки, прагнення до якої декларує Україна, заснована на незалежних власниках, які ведуть господарську діяльність. Однак режим надзвичайного стану передбачає можливість запровадження невиправданих обмежень у сфері економічних відносин, 
які можуть створити передумови для зловживань окремими представниками публічної влади. Так, тільки в умовах воєнного чи надзвичайного стану може бути допустимим примусове відчуження об'єктів права приватної власностіз наступним повним відшкодуванням їх вартості [7]. Проте умови боротьби із пандемією навряд чи потребують такого (навіть теоретичного) жорстокого втручання в непорушне право особи на володіння, користування та розпорядження своїм майном. Вважаємо за необхідне зазначити, що наведені обставини не можуть виправдовувати неконституційність обмеження прав людини, які були запроваджені в Україні під час карантину, зокрема Постановою Уряду «Про запобігання поширенню на території України гострої респіраторної хвороби COVID-19, спричиненої коронавірусом SARS-CoV-2».

Наведені тези наштовхують на думку про те, що чинні конституційні механізми не були розраховані на сучасні види епідемічних загроз. Тому доречно поміркувати над розробкою альтернативного правового сценарію для таких небезпек як COVID-19.

Чинна Конституція передбачає два особливих правових режими: воєнного та надзвичайного стану. Проте, якщо аналізувати законодавство, то можна зрозуміти, що надзвичайний стан (який нас найбільше зараз цікавить) $є$ загальним механізмом для різноманітних варіантів подій: від ситуацій техногенного та природного характеру до спроби захоплення державної влади чи зміни конституційного ладу України шляхом насильства. Водночас запровадження спеціального конституційного сценарію для загроз рівня пандеміі COVID-19 могло би бути менш обтяжливим, ніж запровадження надзвичайного стану. 3 огляду на зазначене пропонуємо розглянути можливість запровадження в Конституції особливого режиму епідеміологічної небезпеки, зміст якого відповідав би наявним викликам конституційним правам людини.

Крім того, доцільно ввести в доктрину конституційного права поняття «конституційний сценарій». Під ним слід розуміти передбачену приписами Конституції системно організовану процедуру прийняття рішень, наслідками яких є обмеження конституційних прав особи задля відвернення нагальних критичних загроз. Видами конституційного сценарію $є$ воєнний стан, надзвичайний стан і стан епідеміологічної небезпеки.

Ці міркування не дають підстав для висновку про наявність прогалин в Конституції. Це пов’язано з розрізненням Конституції, яка сприймається як деякий формалізований текст, та Конституції, яка являє собою систему цінностей, що розвиваються в практиці суду конституційної юрисдикції. Саме в останньому розумінні Конституцію можна вважати безпрогальною. Бачення Конституції суто як формалізованого тексту спростовує презумпцію безпрогальності. За інших умов потреба існування механізму внесення змін до Конституції (Розділ ХІІІ) суперечила би ідеї безпрогальності.

Механізмом забезпечення прямої дії конституційних прав в умовах сучасної пандемії можна також визнавати презумпиію верховенства прав людини. Як вияв прямої дії ця презумпція зумовлена невичерпним характером прав і свобод людини та їх визначальною роллю у конституційному регулюванні. Як зазначив з цього приводу В. Гончаров, «Конституція вміщує презумпцію про права людини, зобов'язуючи Конституційний Суд України до перевірки необхідності їх обмежень з боку держави» [10, с. 179].

Проте не можна погодитись із тим, що функції цієї презумпції полягають виключно в перевірці необхідності обмежень прав людини судом конституційної юрисдикції, особливо коли є необхідність прийняття оперативних 
рішень задля уникнення масового обмеження конституційних прав.

У цьому контексті варто звернути увагу на чинні редакції процесуальних кодексів. Наприклад, частиною четвертою статті 7 Кодексу адміністративного судочинства України передбачено, що «у випадку коли суд доходить до висновку, що закон чи інший правовий акт суперечить Конституції, суд не застосовує такий закон чи інший правовий акт, а застосовує норми Конституції України як норми прямої дії» [11].

Не вдаючись до дискусій 3 приводу проблем втілення цієї норми у правозастосовній практиці, погоджуємося із позицією С. Різника, який розглядає таку процесуальну можливість суду як проміжну форму конституційного контролю, що полягає у перевірці загальними судами конституційності Законів України [12, с. 163]. Цей механізм, який є однією 3 форм втілення презумпції верховенства прав людини, допомагає забезпечувати реалізую приписів Конституції, в яких втілені права людини, як норм прямої діï. Своєю чергою, він може бути використаний як дієвий інструмент захисту прав людини в сучасних умовах.

Показово, що на початку квітня 2020 року до Окружного адміністративного суду міста Києва надійшов позов щодо оскарження вже згаданого обмеження права на вільне пересування, передбаченого Постановою Уряду № 211. Позивач просив суд визнати протиправною та нечинною цю Постанову в частині, що стосується заборони з 6 по 24 квітня 2020 року переміщуватись групою більше ніж із двох осіб, відвідувати парки, сквери, зони відпочинку та спортивні майданчики, а також перебувати на вулиці без документів, що посвідчують особу [13]. Розглядаючи цю справу, суд міг би використати сучасний потенціал адміністративного судочинства в частині проміжного конституційного контролю. Таким чином, цей інструмент конституційного контролю як вияв презумпцї верховенства прав людини може стати дієвим інструментом захисту конституційного ладу від протиправних посягань із боку держави в умовах пандемії.

Наостанок залишилось розглянути такий елемент прямої дії конституційних прав, як їх автономне тлумачення. Ця категорія не є новою для науки конституційного права. Не викликає сумніву також і те, що Конституція містить значну кількість концепцій, для застосування яких необхідне розкриття не лише ї матеріального змісту, але також і спеціальних чи специфічних елементів процедури їх реалізації. Багато з них мають дуалістичну природу, оскільки вони втілені також на рівні вторинного законодавства, де, як правило, їх інтерпретація здійснюється через застосування норм-дефініцій (білышого чи меншого ступеня деталізаціi). Однак зміст згаданих норм-дефініцій, не можна ототожнювати зі змістом ïх аналогів у Конституціі. Заперечення цього підходу сприятиме поглинанню останньої звичайними законами, що може мати наслідком звуження змісту та обсяг конституційних прав. Наведена думка знайшла своє підтвердження у практиці Конституційного Суду, який у справі № 1-13/2016 визнав, що «iз положень про пряму дію норм Конституції випливає, що законами України та іншими нормативно-правовими актами можна лише розвивати конституційні норми, а не змінювати їх зміст» [14].

У контексті сучасних викликів перед правами людини ця складова частина прямої дії конституційних прав може бути використана як інструмент запобігання свавільному використанню тексту Конституції органами державної влади шляхом зміни змісту конституційних категорій. Серед усього іншого зазначений елемент прямої дії здатний обмежити звужене тлумачення конституційних прав у спосіб, що не відповідає змісту Конституції.

Підсумовуючи, можна зробити висновок, що дієвим інструментом 
захисту конституційних прав людини, особливо в кризові періоди, може стати пряма дія конституційних прав людини. Пряма дія конституційних прав не допускає свавільного використання тексту Конституції органами державної влади, які можуть змінювати зміст конституційних категорій у спосіб, що надмірно обмежує конституційні права.
Водночас використання потенціалу цього антикризового інструменту потребує осмислення на практичному та науковому рівнях. Означений конституційний інструмент охорони та захисту конституційного ладу та конституційних прав людини потребує подальшої перевірки на життєдіяльність в наукових дискусіях і в Конституційному Суді України.

\section{Список використаних джерел}

1. Летнянчин Л.І. Пряма дія норм Конституції України: від принципу - до практичного застосування. Вісник Нащіональної академії правових наук України. № 4 (91). 2017. C. 115-127. URL : http://visnyk.kh.ua/web/uploads/pdf/_VA=8_4_2017-115-127. $\operatorname{pdf}(17.05 .2020)$.

2. Савчин М.В. Сучасні тенденції конституціоналізму у контексті глобалізації та правового плюралізму : монографія. Ужгород : РІК-У, 2018. С. 440.

3. Голєв О. Інтегральне розуміння прямої дії конституційних прав і свобод людини у світлі конституційного судочинства. Юридичний науковий електронний журнал. № 5 , 2019. C. 40-44. URL: http://www.lsej.org.ua/5_2019/9.pdf(17.07.2020).

4. Рішення Конституційного Суду України № 8-р/2018 від 11 жовтня 2018 р.

5. Постанова Кабінету Міністрів України № 211 «Про запобігання поширенню на території України гострої респіраторної хвороби COVID-19, спричиненої коронавіруcoм SARS-CoV-2» від 11.03.2020 року (в редакції від 04.04.2020 року).

6. Рішення Конституційного Суду України № 1-р/2017 від 23 листопада 2017 р.

7. Конституція України від 28.07.1998 (зі змінами). URL : https://zakon.rada.gov. ua/laws/show/254\%D0\%BA/96-\%D0\%B2\%D1\%80\#Text (17.07.2020).

8. Рішення Конституційного Суду України № 10-р/2020 від 28 серпня 2020 року.

9. Закон України «Про правовий режим надзвичайного стану» від 16.03.2000 року. URL : https://zakon.rada.gov.ua/laws/show/1550-14 (17.07.2020).

10. Гончаров В. В. Презумпція про права людини та презумпція конституційності нормативних актів. Право України. 2015. № 2. С. 175-185.

11. Кодекс адміністративного судочинства від 06.07.2006 року. URL : https://zakon.rada.gov.ua/laws/show/2747-15\#Text (17.07.2020).

12. Різник С.В. Перевірка судами загальної юрисдикції конституційності Законів України як проміжна форма конституційного контролю (у контексті права особи на конституційну скаргу). Право України. 2018. № 12. С. 163-177.

13. Офіційний сайт Окружного адміністративного суду міста Києва. В ОАСК оскаржують встановлені Урядом обмеження на переміщення осіб з 6 по 24 квітня 2020 року. URL : http://oask.gov.ua/node/4410 (17.07.2020).

14. Рішення Конституційного Суду України № 6-рп/2016 від 8 вересня 2016 р.

Голєв О. Є. Пряма дія конституційних прав людини як антикризовий інструмент охорони та захисту прав людини в умовах пандемії COVID-19

Кризові процеси в Україні та світі, що пов’язані із тривалим поширенням COVID-19, формують нові виклики для світового співтовариства, чи не найскладнішим з яких $€$ пошук балансу між необхідністю введення карантинних заходів, метою яких є забезпечення безпеки усіх і кожного, та окремими правами людини.

У сучасних умовах існує необхідність розробки антикризового інструменту, що допоможе захистити конституційні права та конституційний лад. Дієвим інструментом захисту 
конституційних прав людини можна визнати їх пряму дію, яка випливає зі статті 8 Конституції України. Тому метою цієї статті є розкриття значення і ролі прямої дії конституції в якості інструментарію подолання кризових явищ у світлі доктрини прав людини.

У цій статті продовжено дослідження складових частин прямої дії конституційних прав, які мають практичний потенціал для підвищення рівня захисту прав людини. Зокрема, запропонований механізм забезпечення прямої дії конституційних прав може бути застосований під час розв'язання проблемних питань, які виникають під час пандемії COVID-19.

Аргументовано, що дієвим інструментом захисту конституційних прав людини, особливо в кризові періоди, може стати пряма дія конституційних прав людини. Зроблено висновок, що пряма дія конституційних прав не допускає свавільного використання тексту Конституції органами державної влади, які можуть змінювати зміст конституційних категорій у спосіб, що надмірно обмежує конституційні права.

У статті розглянуто можливість запровадження в Конституції особливого режиму епідеміологічної небезпеки, зміст якого відповідав би наявним викликам конституційним правам людини. Запропоновано ввести в доктрину конституційного права поняття «конституційний сценарій». Під ним слід розуміти передбачену приписами Конституції системно організовану процедуру прийняття рішень, наслідками яких є обмеження конституційних прав особи задля відвернення нагальних критичних загроз. Видами конституційного сценарію $€$ воєнний стан, надзвичайний стан і стан епідеміологічної небезпеки.

Ключові слова: пряма дія конституційних прав, виключний предмет правового регулювання Конституції, конституційний сценарій, COVID-19, презумпція верховенства прав людини, автономне тлумачення, безпрогальність Конституції.

Holiev O. Direct applicability of constitutional rights as an anti-crisis instrument of human rights protection in the context of the COVID-19 pandemic

Crisis in Ukraine and all around the world, concerned the expansion of COVID 19, has shaped a new challenges for the international community, while the most sophisticated one is the search for a proper balance between the necessity to introduce the quarantine measures (tailored to ensure the security of the population in general) and the particular human rights.

Nowadays a necessity to develop a sort of counter-crisis toolkit to support the constitutional rights and constitutional order has emerged. The direct applicability and effect of the constitutional rights, as provided by Clause 8 of the Constitution of Ukraine, is to be regarded as the most valuable tool to prevent the breach thereof. Hence, this Article is going to explore the functional components of the direct effect of the constitutional rights - those concerned the practical outcome to enhance the level of the human rights protection.

This Article provides for further research on key elements of the direct applicability of the constitutional rights principle - as having a practical outcome in the field of the human rights protection. Inter alia, a procedure of the direct application of the constitutional rights, proposed by the Article, may as well be applied to counter the COVID-19-related threats.

It is argued, that the direct effect of the constitutional provisions may be regarded as the effective instrument for the human rights protection, especially at the times of crisis. It is opined, that due to the constitutional rights direct applicability concept, no arbitrary employment of the Constitutional provisions by the governmental authorities, causing the stuffing of the constitutional rights meaning and rationale, may be tolerated.

The Article also discuss the possibility to introduce to the Constitution a corpus of rules concerned the extreme level of the epidemiological danger, aligned with the relevant challenges and needs of the human rights protection. Besides, it is proposed to bring into constitutional provisions a constitutional scenario concept. This scenario shall refer to the stipulated at the Constitution specially-designed procedure of the decision adoption in the times of urgent crisis dangers - in case these decisions may lead to the restriction of human rights.

Key words: direct applicability of constitutional rights, exclusive province of constitutional regulation, constitutional scenario, COVID-19, primacy of human rights presumption, autonomous interpretation, gaps (no) in Constitution. 